\title{
DIVERSITY OF PLUTONIC ROCKS IN THE OCEANIC CRUST: THE THVERARTINDUR CENTRAL VOLCANIC COMPLEX, SE ICELAND
}

\author{
Alvar SOESOO \\ Nordic Volcanological Institute, University of Iceland, IS-101, Reykjavik, Iceland \\ Present address: Eesti Teaduste Akadeemia Geoloogia Instituut (Institute of Geology, \\ Estonian Academy of Sciences), Estonia pst. 7, EE-0001 Tallinn, Eesti (Estonia)
}

Presented by V. Puura

Received 27 April 1995, accepted 8 June 1995

\begin{abstract}
Iceland, with the plate boundary exposed on land, represents a natural laboratory for observing the petrology and tectonics of the mid-ocean ridge environment interacting with a deep mantle plume. The specific chemical characteristics of Icelandic igneous rocks, such as high abundance of incompatible trace elements, high ${ }^{87} \mathrm{Sr} /{ }^{86} \mathrm{Sr}$, low ${ }^{143} \mathrm{Nd} /{ }^{144} \mathrm{Nd}$ and radiogenic $\mathrm{Pb}$ contents result from plume influences on the magma generation and its subsequent evolution in crustal magma chambers inside the anomalously thick Icelandic crust $(8-20 \mathrm{~km})$ and interaction with the altered old crust.

The Tertiary Thverartindur central volcanic complex in SE Iceland offers 2-km-deep erosional sections and exhibits a large variety of intrusive rocks from ultramafic, through olivine- and quartz-tholeiites, hybrid rocks to acid in the chemical composition. Wehrlitic ultramafic rocks consist of olivine $\left(\mathrm{Fo}_{69-91}\right)$ and/or clinopyroxene $\left(\mathrm{En}_{42-45} \mathrm{Fs}_{12-14} \mathrm{Wo}_{42-43}\right)$. Gabbros are fine- to very coarse-grained, melano- to leucocratic with plagioclase (average $A_{45-65}$ ) and clinopyroxene (average $\mathrm{En}_{40-43} \mathrm{Fs}_{15-25} \mathrm{Wo}_{35-42} ; 80-95 \mathrm{vol} \%$ ), magnetite and/or ilmenite $(<10 \%)$ with minor olivine, quartz, apatite, hornblende, biotite, and alteration minerals. Hybrid rocks consist of plagioclase $\left(\mathrm{An}_{26-72}\right)$, clinopyroxene $\left(\mathrm{En}_{32-39} \mathrm{Fs}_{19-28} \mathrm{Wo}_{39-41}\right)$, magnetite, ilmenite, and quartz with minor hornblende, apatite, epidote, sphene, zircon, and alteration minerals. They clearly exhibit different generations of minerals and abridge the compositional gap between quartztholeiite and granite. Granitic rocks display granophyric textures, contain up to 60 vol\% quartz and $20-60 \mathrm{vol} \%$ feldspar with $10-16$ vol\% normative orthoclase, and define a distinctive evolutionary trend from 65 to $80 \mathrm{wt} \% \quad \mathrm{SiO}_{2}$.

This rock diversity is a result of multiple magmatic processes: (i) fractional crystallization in the probably refilled crustal magma chamber; (ii) mixing between basic and acid magmas, and mixing of earlier formed crystals with more evolved basic magma. The $\mathrm{Fe}$-Ti-enrichment accompanied by $\mathrm{Si}$-decrease in quartz-tholeiitic gabbros can most easily be explained by a $50-70 \%$ crystallization of an olivine-tholeiitic composition in NNO oxygen buffer following the equilibrium/fractional crystallization path.
\end{abstract}

Key words: oceanic crust, petrology, central volcano, plutonic rocks, magmatic processes, Iceland.

\section{INTRODUCTION}

Iceland is a part of the oceanic crust representing a combination of the oceanic ridge and the Icelandic hot spot which has been active since before the opening between Greenland and Norway. In general, the rock formations get younger towards the centre of the island, but as the 


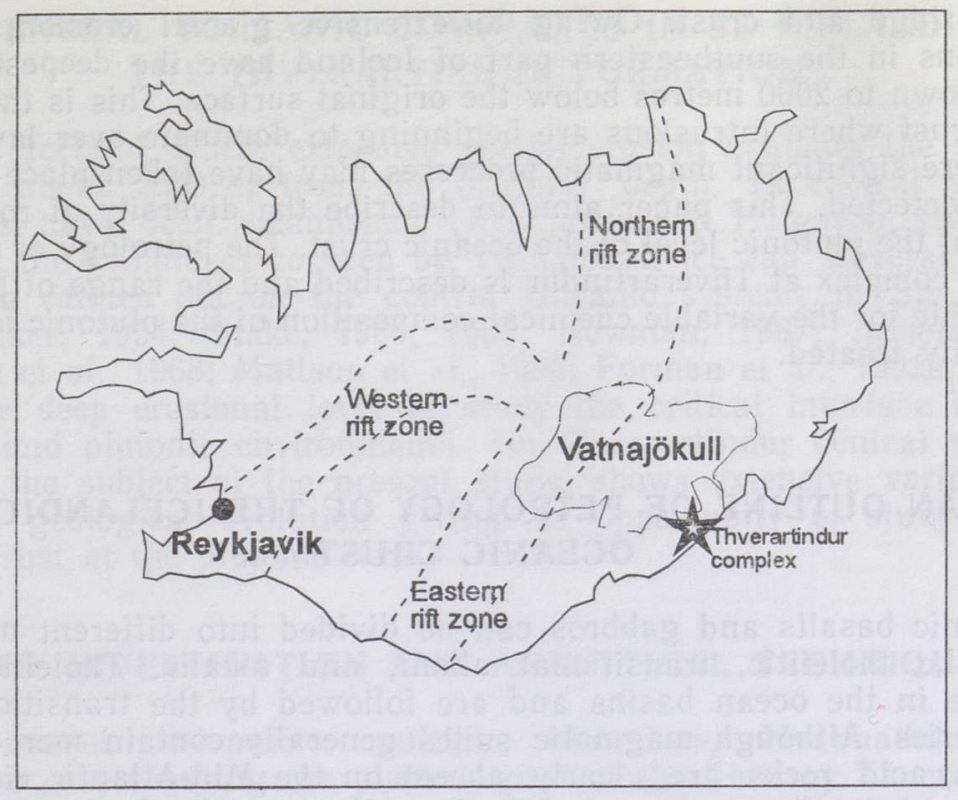

Fig. 1. Sketch map of Iceland. Neovolcanic (active rifting) zones and Tertiary Thverartindur central volcanic complex are shown.

relative positions of the plume centre and the plate boundary in Iceland have changed in the course of time, there has occurred a series of ridge jumps and ridge propagation episodes.

The Icelandic crust is thicker than normally on the oceanic ridges, reflecting higher magmatic production rates due to higher mantle temperatures (White \& McKenzie, 1989), and the range of rock types is more varied. The estimated thickness of the crust in Iceland varies from 8 to over $20 \mathrm{~km}$ being anomalously thick compared to that of $3-8 \mathrm{~km}$ for a normal oceanic crust. At present, the spreading activity is confined to the Western, Eastern, and Northern neovolcanic (rift) zones (Fig. 1). The tectonic activity of the main rift zones is concentrated in elongated segments while the volcanic activity is confined to the main rift zones and to certain off-rift volcanic systems. Each volcanic/tectonic system is composed of a set of parallel eruptive ridges or fissures, constituting a fissure swarm that varies in length from 17 to $105 \mathrm{~km}$, in width from 5 to $30 \mathrm{~km}$ (Jakobsson, 1979). The life span of such systems may vary from 300000 to 500000 years. These swarms may in time develop a central volcano the lifetime of which is from about 300000 to 1000000 years (Saemundsson, 1979). This kind of a volcano is topographically elevated relative to the surroundings due to increased magma extrusion at one site. Shield volcanoes or lava shields of different sizes (up to $15 \mathrm{~km}^{2}$ ) are found randomly within the volcanic rift zones. It is important to mention that the volcanic morphology is greatly dependent on whether the eruption occurs under ice or subaerally. The half-spreading rate is $10 \mathrm{~mm} / \mathrm{yr}$ in Iceland, while those for southern zones of the Atlantic are $11-12 \mathrm{~mm} / \mathrm{yr}$ for the Azores and $15 \mathrm{~mm} / \mathrm{yr}$ for the Kane Fracture Zone.

Iceland, where the Mid-Atlantic plate boundary is exposed on land, gives a unique opportunity to study the structure and composition of an 
oceanic ridge and crust. Owing to extensive glacial erosion, the rock formations in the southeastern part of Iceland have the deepest erosion levels, down to 2000 metres below the original surface. This is the section of the crust where intrusions are beginning to dominate over lava flows, and where significant magmatic processes may have taken place and can still be detected. This paper aims to describe the diversity of rocks near the top of the plutonic level of the oceanic crust. The petrology of a central volcanic complex at Thverartindur is described and the range of processes responsible for the variable chemical composition of the plutonic formation are briefly treated.

\section{AN OUTLINE OF PETROLOGY OF THE ICELANDIC OCEANIC CRUST}

Oceanic basalts and gabbros can be divided into different magmatic series like tholeiitic, transitional alkali, and alkalic. Tholeiitic rocks dominate in the ocean basins and are followed by the transitional and alkali series. Although magmatic suites generally contain more evolved members, acid rocks are clearly absent on the Mid-Atlantic ridge. The evolved compositions characterize the Atlantic islands (e.g. Iceland, Azores, Canaries). Specific chemical features allow us to distinguish normal oceanic basalts, MORBs, from oceanic island basalts, OIBs.

In Icelandic rift zones olivine- and quartz-tholeiites are the dominant eruptive products. Olivine tholeiites can be erupted randomly within the rift zones but the more evolved parts of the tholeiitic suites (quartztholeiites), having high iron and low magnesium contents compared to typical MORBs, are mainly confined to the volcanic/tectonic swarms. There has been much discussion on whether these two types of basic rocks are related to each other by simple fractional crystallization or whether they are derived from different magma batches and have different fractional crystallization histories. Alkalic and transitional rocks, similar to those observed for oceanic islands, are confined to the off-rift volcanism. Alkali rocks appear in two areas, the Vestmann Islands in southern Iceland, and Snaefellsness volcanic system in western Iceland (Steinthorsson et al., 1985). The Austurhorn Tertiary volcanic complex in southeastern Iceland is believed to represent transitional alkali series (Furman et al., 1992a, 1992b).

There are 29 volcanic systems currently active in Iceland; four of these are alkaline, seven are transitional and the rest are tholeitic. Acid and intermediate rocks form $9 \%$ of the erupted products being associated particularly with the central volcanoes (Saemundsson, 1979).

The high abundance of incompatible trace elements, high ${ }^{87} \mathrm{Sr} /{ }^{86} \mathrm{Sr}$, low ${ }^{143} \mathrm{Nd} /{ }^{144} \mathrm{Nd}$ and radiogenic $\mathrm{Pb}$ contents (O'Nions et al., 1977; Hemond et al., 1993) and additionally, a light oxygen enrichment of rocks in volcanic centres of the rift zones (Condomines et al., 1983) are distinctive features of Icelandic rocks. These features have been explained by two different processes which are not necessarily mutually exclusive. Firstly, chemical and isotopic heterogeneities may exist in the mantle (e.g. Zindler et al., 1979). Secondly, ascending magmas may interact with the old, hydrothermally altered crust (e.g. Oskarsson et al., 1982; Nicholson et al., 1991). Oxygen isotope results (Hemond et al., 1993) distinguish two groups, like quartz-tholeiites and more evolved rocks with low $\delta^{18} \mathrm{O}$ values resulting from interactions with the hydrothermally altered Icelandic crust that contrasts with picrites, olivine-tholeiites, and alkali basalts with a normal mantle $\delta^{18} \mathrm{O}$ compositions. 


\section{CENTRAL VOLCANIC COMPLEXES IN SE ICELAND: THE THVERARTINDUR FORMATION}

In SE Iceland, where extensive glacial erosion exhumes the sections down to about $2000 \mathrm{~m}$ from the original depth, 19 central volcanic complexes have been established (Kristjansson \& Helgason, 1988) not including the complexes covered by Vatnajökull ice cap. Several studies have been carried out on the central volcanic systems in SE Iceland (e.g. Walker, 1964; Blake, 1964, 1966; Newman, 1967; Annels, 1967; Moorbath et al., 1968; Mattson et al., 1986; Furman et al., 1992a, 1992b) using the deep erosional level to study the critical interface between volcanic and plutonic environments. The Thverartindur central volcanic complex, the subject of the present study, shows extensive variation in rock and geological evolution giving an opportunity of studying the oceanic crust at the plutonic level.

\section{FIELD INVESTIGATION AND ANALYTICAL TECHNIQUES}

Two major composite multiple intrusives, Hvannadalur and Fellsadalur, representing the plutonic part of the Tertiary Thverartindur central volcanic complex, were mapped during the 1993/94 field seasons. Rock samples were collected to cover the variation in rock subtypes, then representative samples were selected to characterize chemical features of the main rock units. The analyses of major and trace elements were performed by ICP, Rb was analysed using AAS (Nordic Volcanological Institute, University of Iceland), and 28 samples were analysed for $\mathrm{Nb}$, $\mathrm{Ga}$, and repeatedly for $\mathrm{Sr}$ and $\mathrm{Rb}$ using X-ray fluorescence technique at the Institute of Geology in Estonia. For preliminary petrological testing and some calculations, the NewPet and CSS computer software were employed.

Sixteen samples were selected for electron microprobe study. The analyses were performed on an ARL-SEMQ instrument at Nordic Volcanological Institute. The analytical conditions for olivine, oxides, and clinopyroxene were: beam potential $15 \mathrm{kV}$, sample current $80 \mathrm{nA}$, and the counting times of 10 seconds for peak and 4 seconds for the background. Plagioclase was analysed at $15 \mathrm{kV}$ and $25 \mathrm{nA}$, with the counting times of 20 seconds (peak) and 4 seconds (background). Natural minerals and metals were used as standards.

\section{DIVERSITY OF ROCK TYPES OF THE THVERARTINDUR COMPLEX}

The Thverartindur area (Fig. 1) is dominated by late Tertiary plateau basalts and hyaloclastites exhibiting a shallow regional dip towards NNE. Only a few age determinations have been made on the plutonic rock suites in SE Iceland. These estimations give a time span of $2.2-7 \mathrm{Ma}$ (Gale et al., 1966; Moorbath et al., 1968), where the granophyres from the Hvannadalur pluton display the youngest age of about $2.2 \mathrm{Ma}$. The distance from the present rift zone gives the expected age of slightly less than $7 \mathrm{Ma}$. The estimated age of granitic rocks implies a long-living magmatic system which probably continued magmatic evolution long after the main rifting episode had ceased or a rift jump did occur.

The Hvannadalur and Fellsadalur gabbro-granophyric intrusions located in deep glacial valleys are believed to be related to a common shallow magma chamber (Bromann \& Soesoo, 1994). The gabbro intrusions consist of multiple subparallel 15-80-m-thick melanocratic to leucocratic 


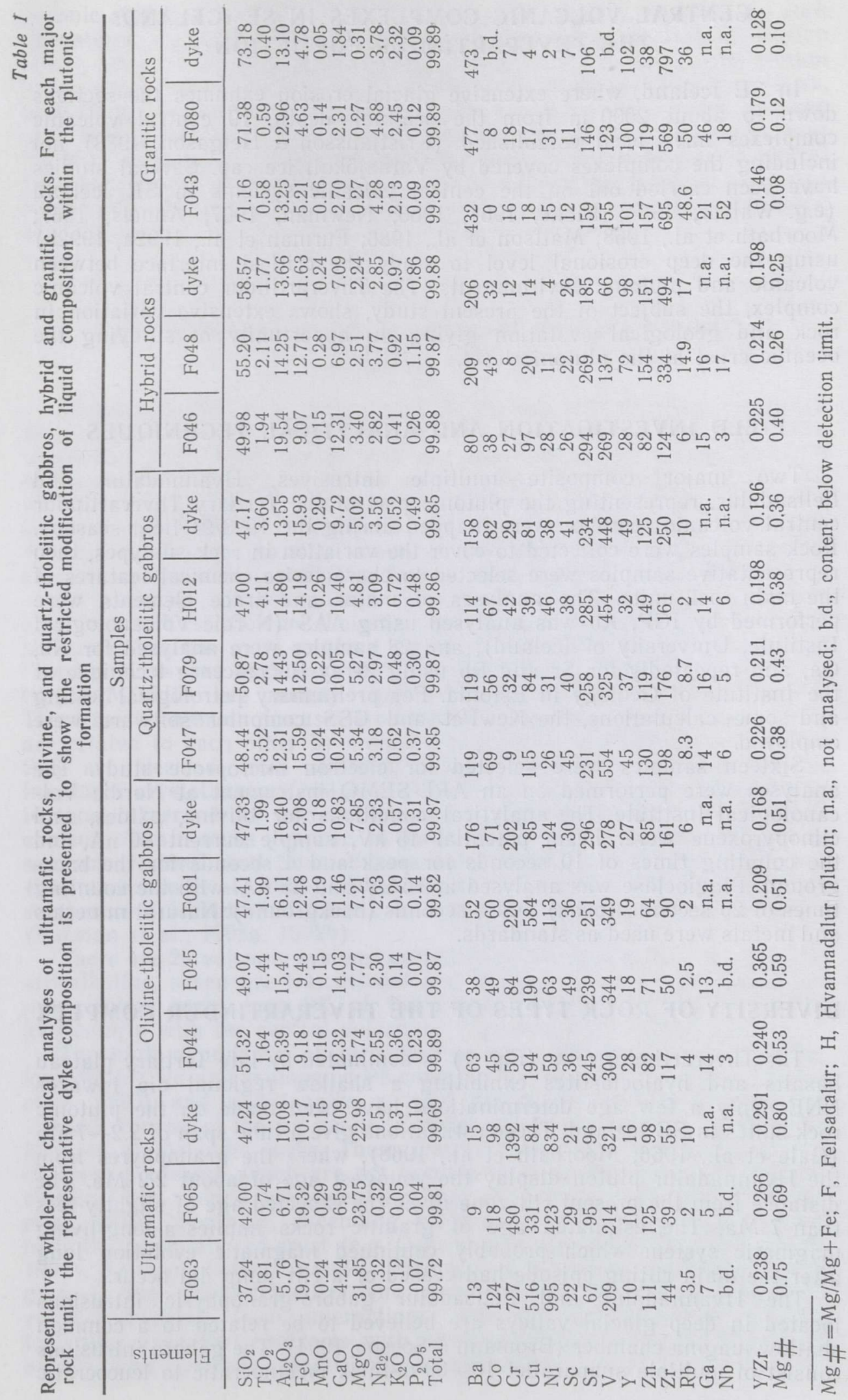




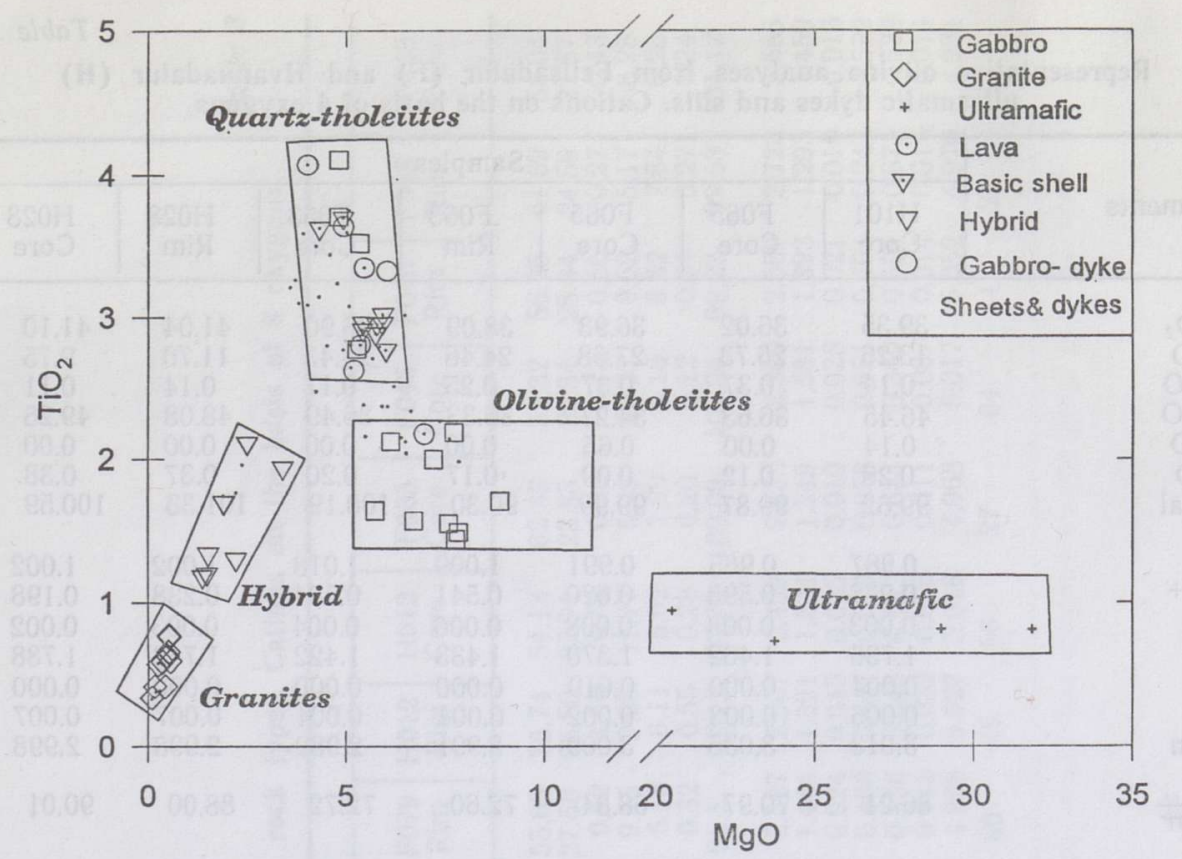

Fig. 2. Olivine- and quartz-tholeiites, ultramafic and hybrid rocks, and granites distinguished on the $\mathrm{MgO}-\mathrm{TiO}_{2}$ classification diagram. Note that the dyke compositions occupy the space between olivine- and quartz-tholeiitic gabbros showing gradual change in magma chemistry in the evolutionary context.

sills, which are cut by $0.5-3-\mathrm{m}$-thick ultramafic sills. Granophyric rocks, surrounding the gabbro bodies, are enveloped by a very fine-grained basic intrusive rock type separating the intrusions from the surrounding lavas. The multiple emplacement history of gabbroic sills is supported by compositionally and texturally different gabbros and ultramafic xenoliths and chilled margins between sills. The mafic part of the intrusions has all characteristics of sills, emplaced most probably from a common magma chamber, and the granophyres form a huge body (up to $3-4 \mathrm{~km}^{3}$ ) accompanied by some sheets propagating from the top of the acid body.

The Thverartindur gabbros (Table 1) are fine- to very coarse-grained, melano- to leucocratic plagioclase (average $A_{45}-65$ ), and clinopyroxene (Cpx; average $\mathrm{En}_{40-43} \mathrm{Fs}_{15-25} \mathrm{Wo}_{35-42} ; 80-95$ vol\%), magnetite and/or ilmenite $(<10 \%)$ rocks containing minor olivine, quartz, apatite, hornblende, biotite, and alteration minerals, such as iddingsite, calcite, and chlorites as an accessory phase. They do not exhibit cumulate textures and there is compositional overlapping of the minor and major intrusive units as shown in Fig. 2. Whole-rock major element composition and normative mineralogy separate the gabbros into olivine- and quartz-tholeiitic units (Fig. 2) with the Mg\# number ranging from 39 to 61.

Representative olivine, plagioclase, and clinopyroxene analyses are presented in Tables 2, 3, and 4. In Fig. 3, the En, Wo, Fs, and An components in clinopyroxene and plagioclase are shown. The $\mathrm{Zr}$ content in the whole-rock chemistry is used as an evolutionary index distinctively separating the rock units defined. It is significant that there is no clear difference between quartz- and olivine-tholeiitic gabbros expressed in the mineral compositions (Fig. 3). Slight trends are displayed by the Fs component in $\mathrm{Cpx}$ and the An component in plagioclase, which show some Fe-enrichment and $\mathrm{Ca}$-depletion, respectively. One olivine-tholeiitic sample, 
Representative olivine analyses from Fellsadalur (F) and Hvannadalur (H) ultramafic dykes and sills. Cations on the basis of 4 oxygens

\begin{tabular}{l|r|r|r|r|r|r|r}
\hline \multirow{2}{*}{ Elements } & \multicolumn{7}{|c}{ Samples } \\
\cline { 2 - 8 } & $\begin{array}{c}\text { H101 } \\
\text { Core }\end{array}$ & $\begin{array}{c}\text { F065 } \\
\text { Core }\end{array}$ & $\begin{array}{c}\text { F065 } \\
\text { Core }\end{array}$ & $\begin{array}{c}\text { F063 } \\
\text { Rim }\end{array}$ & $\begin{array}{l}\text { F063 } \\
\text { Core }\end{array}$ & $\begin{array}{l}\text { H028 } \\
\text { Rim }\end{array}$ & $\begin{array}{c}\text { H028 } \\
\text { Core }\end{array}$ \\
\hline $\mathrm{SiO}_{2}$ & 39.35 & 36.02 & 36.93 & 38.09 & 38.90 & 41.04 & 41.10 \\
$\mathrm{FeO}$ & 13.26 & 26.73 & 27.68 & 24.46 & 24.43 & 11.70 & 9.75 \\
$\mathrm{MnO}$ & 0.14 & 0.37 & 0.37 & 0.25 & 0.17 & 0.14 & 0.11 \\
$\mathrm{MgO}$ & 46.45 & 36.63 & 34.27 & 36.33 & 36.49 & 48.08 & 49.25 \\
$\mathrm{CaO}$ & 0.14 & 0.00 & 0.65 & 0.00 & 0.00 & 0.00 & 0.00 \\
$\mathrm{NiO}$ & 0.28 & 0.12 & 0.09 & 0.17 & 0.20 & 0.37 & 0.38 \\
$\mathrm{Total}$ & 99.62 & 99.87 & 99.99 & 99.30 & 100.19 & 101.33 & 100.59 \\
$\mathrm{Si}$ & 0.987 & 0.965 & 0.991 & 1.009 & 1.018 & 1.002 & 1.002 \\
$\mathrm{Fe}$ & 0.278 & 0.598 & 0.620 & 0.541 & 0.534 & 0.238 & 0.198 \\
$\mathrm{Mn}$ & 0.003 & 0.008 & 0.008 & 0.006 & 0.004 & 0.003 & 0.002 \\
$\mathrm{Mg}$ & 1.736 & 1.462 & 1.370 & 1.433 & 1.422 & 1.748 & 1.788 \\
$\mathrm{Ca}$ & 0.004 & 0.000 & 0.019 & 0.000 & 0.000 & 0.000 & 0.000 \\
$\mathrm{Ni}$ & 0.006 & 0.003 & 0.002 & 0.004 & 0.004 & 0.007 & 0.007 \\
$\mathrm{Sum}$ & 3.013 & 3.035 & 3.009 & 2.991 & 2.982 & 2.998 & 2.998 \\
$\mathrm{Fo} \#$ & 86.21 & 70.97 & 68.84 & 72.60 & 72.72 & 88.00 & 90.01 \\
& & & & & & &
\end{tabular}

FE081, exhibits two distinctive generations of $\mathrm{Cpx}$ although no plausible chemical characteristics indicate the hybridizational (mixing) origin of this gabbro. A remarkable feature of Thverartindur gabbros is the lack of Ca-poor pyroxene and exsolutions. Clinopyroxenes are usually rather uniform in composition. Quartz-tholeiitic gabbros yield $\mathrm{Cpx}$ with the $\mathrm{Fe}-\mathrm{Mg}$ mineral/bulk partitioning coefficients expected from growth under equilibrium conditions.

Ultramafic sills and dykes are medium- to coarse-grained (Table 1) and consist of olivine $\left(\mathrm{Fo}_{69-91}\right)$ and/or clinopyroxene $\left(\mathrm{En}_{42-45} \mathrm{Fs}_{12-14} \mathrm{Wo}_{42-43}\right)$ (see also Tables 2,4$)$. Minor minerals are plagioclase $\left(\mathrm{An}_{59-70}\right)$, magnetite, ilmenite, Cr-spinel, and chromite. The ultramafic rocks are sometimes slightly nepheline-normative containing $37-44$ wt $\% \quad \mathrm{SiO}_{2} . \quad \mathrm{K}_{2} \mathrm{O}$ and $\mathrm{Na}_{2} \mathrm{O}$ contents are usually low between $0.05-0.5 \mathrm{wt} \%$ and $0.32-0.73$ wt $\%$, respectively. $\mathrm{Mg} \neq$ numbers vary from 69 to 83 .

Hybrid rocks abridge the compositional gap between normal quartztholeitic gabbros and granite, and are represented by clearly different mineral generations suggesting that they are hybrids (Table 1; Fig. 2). They consist of plagioclase $\left(\mathrm{An}_{26-72}\right)$, clinopyroxene $\left(\mathrm{En}_{32-39} \mathrm{Fs}_{19-28}\right.$ $\mathrm{Wo}_{39-41}$ ), magnetite, ilmenite, and quartz with minor hornblende, apatite, epidote, sphene, zircon, and alteration minerals (see Tables 3, 4). Frequently, this rock type exhibits compositionally different plagioclase and/ or clinopyroxene with normal and reverse zoning in the same sample. They have high $\mathrm{K}$ and $\mathrm{Na}$ contents, $0.4-2.9 \mathrm{wt} \%$ and $2.39-5.2 \mathrm{wt} \%$, respectively. There appear to be two types of hybrid rocks differing in the chemical composition, mineralogy, and clinopyroxene composition. The intermediate to acid type (54-65 wt\% of $\mathrm{SiO}_{2}$ ) may be explained by the mixing of basic and acid magmas. A more basic type of hybrid rocks (49 $-55 \mathrm{wt} \%$ of $\mathrm{SiO}_{2}$ ) is abundant in the Fellsadalur intrusion. This could be explained by the mixing of solid crystals with the evolved basic liquid. 


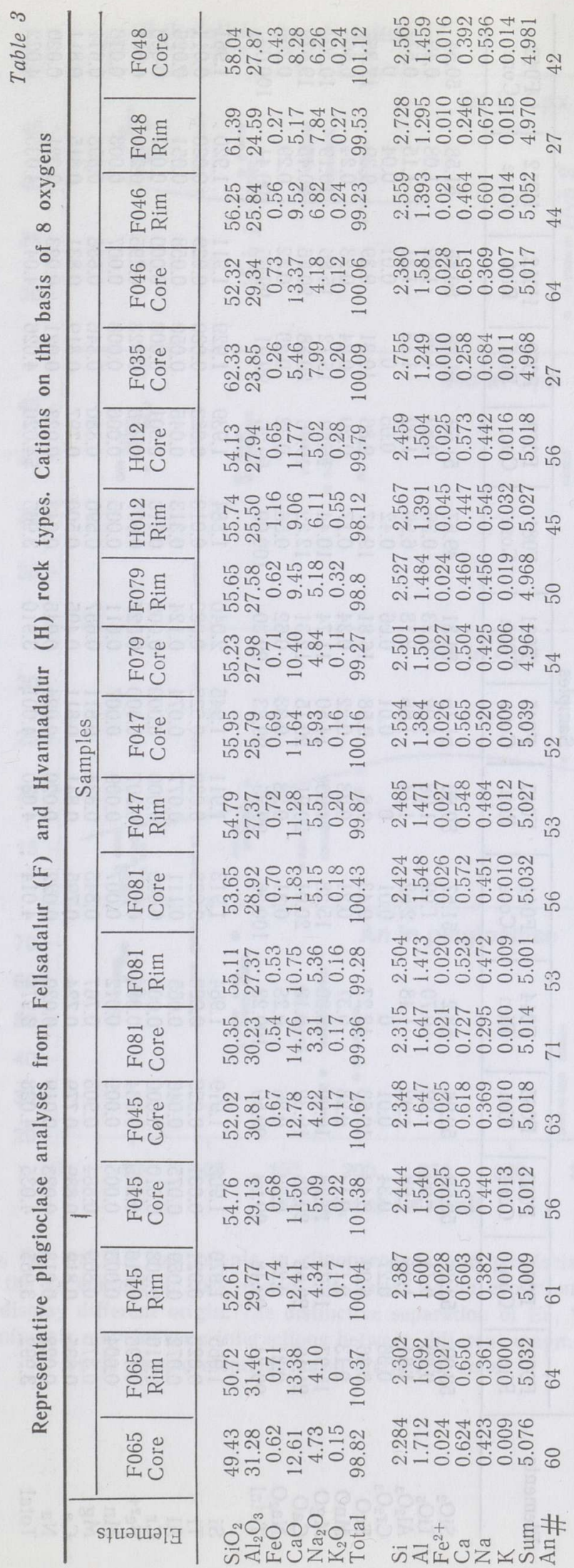




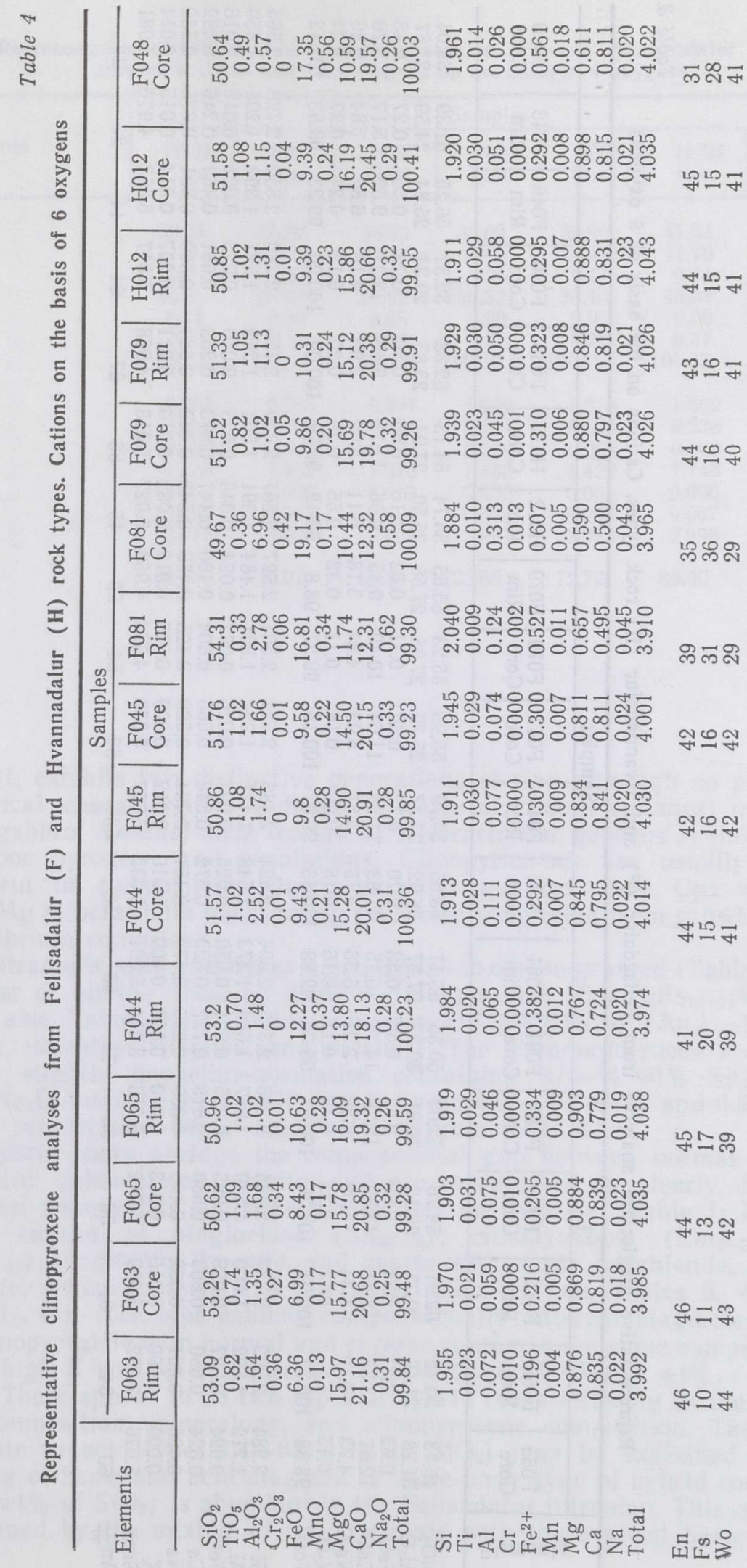




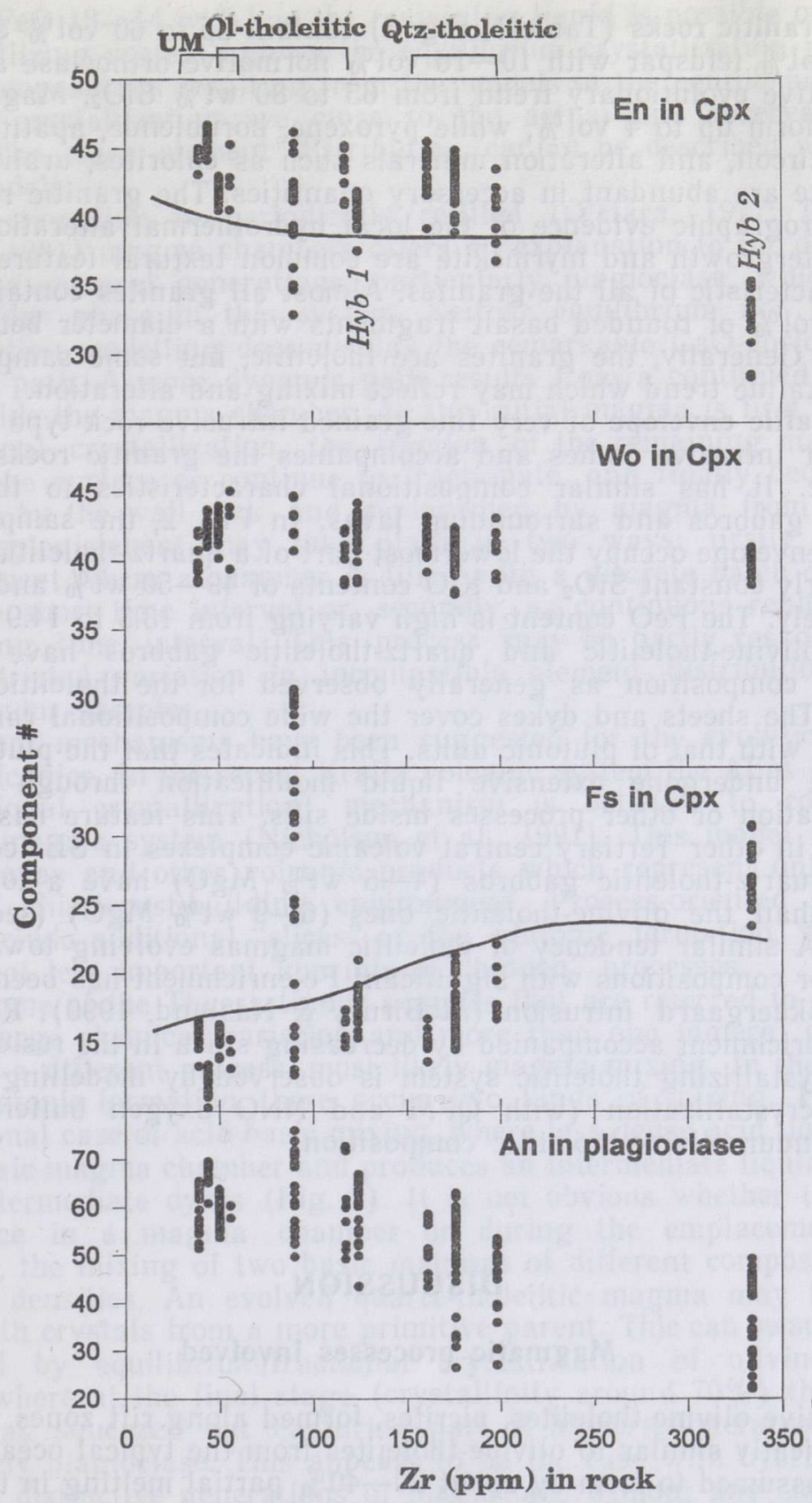

Fig. 3. En, Wo, Fs, and An components in clinopyroxene and plagioclase, respectively plotted against the $\mathrm{Zr}$ content in rock ( $\mathrm{ppm})$, the latter as an evolutionary index. Two hybrid samples display different origin. The distinctive separation of En, Wo, Fs, and An components in minerals may indicate interactions between different magmas and crystals.

Circle size corresponds to an analytical error. 
The granitic rocks (Table 1; Fig. 2) contain up to 60 vol\% quartz and $20-60$ vol\% feldspar with $10-16$ vol\% normative orthoclase and define a distinctive evolutionary trend from 65 to 80 wt $\% \mathrm{SiO}_{2} . \mathrm{Magnetite}$ and ilmenite form up to $4 \mathrm{vol} \%$, while pyroxene, hornblende, apatite, epidote, sphene, zircon, and alteration minerals such as chlorites, uralite, calcite, and pyrite are abundant in accessory quantities. The granitic rocks often show petrographic evidence of the local hydrothermal alteration. Granophyric intergrowth and myrmekite are common textural features, but are not characteristic of all the granites. Almost all granites contain roughly $0.1-10 \mathrm{vol} \%$ of rounded basalt fragments with a diameter between 1 to $300 \mathrm{~mm}$. Generally, the granites are tholeiitic, but some samples lie on a calc-alkaline trend which may reflect mixing and alteration.

A basaltic envelope of very fine-grained intrusive rock type surrounds the major intrusive bodies and accompanies the granitic rocks in space and time. It has similar compositional characteristics to the quartztholeiitic gabbros and surrounding lavas. In Fig. 2, the samples of the basaltic envelope occupy the lowermost part of a quartz-tholeiitic field and have nearly constant $\mathrm{SiO}_{2}$ and $\mathrm{K}_{2} \mathrm{O}$ contents of $49-50$ wt $\%$ and 0.6 wt $\%$, respectively. The $\mathrm{FeO}$ content is high varying from 13.3 to $14.9 \mathrm{wt} \%$.

The olivine-tholeiitic and quartz-tholeiitic gabbros have a similar chemical composition as generally observed for the tholeiitic suites in Iceland. The sheets and dykes cover the wide compositional range which coincides with that of plutonic units. This indicates that the plutonic units have not undergone extensive liquid modification through fractional crystallization or other processes inside sills. This feature has not been observed in other Tertiary central volcanic complexes in SE Iceland.

The quartz-tholeiitic gabbros (4-5 wt $\%$ MgO) have a lower silica content than the olivine-tholeiitic ones (6-9 wt \% MgO) (see Table 1; Fig. 2). A similar tendency of tholeiitic magmas evolving towards more silica-poor compositions with significant Fe-enrichment has been observed in the Skaergaard intrusion (McBirney \& Naslund, 1990). Remarkable Fe-Ti-enrichment accompanied by decreasing silica in the residual liquid in the crystallizing tholeiitic system is observed by modelling the equilibrium crystallization (with QFM and NNO oxygen buffers) of the Thverartindur olivine-tholeiitic composition.

\section{DISCUSSION}

\section{Magmatic processes involved}

Primitive olivine-tholeiites, picrites, formed along rift zones in Iceland are chemically similar to olivine-tholeiites from the typical oceanic ridges and are assumed to form by about $20-40 \%$ partial melting in the mantle beneath Iceland (Jakobsson et al., 1978). Basalts and gabbros, ranging from more evolved olivine-tholeiites to quartz-tholeiites, may be derived by combinations of several magmatic processes:

i) Fractional crystallization in a crustal magma chamber (Biggar, 1983; Oskarsson et al., 1985). This is likely to be an important mechanism of magma evolution but cannot be solely responsible for the wide range of variations described in the Thverartindur complex. The modelling of equilibrium crystallization versus fractional crystallization on two Thverartindur compositions has been performed but it shows significant differences only for $\mathrm{Si}, \mathrm{Ti}$, and $\mathrm{Fe}$ in the evolving systems. The quartztholeiitic compositions may be derived after $50-70 \%$ crystallization of olivine-tholeiites. A very high iron-titanium enrichment $\left(\mathrm{TiO}_{2}\right.$ up to 
4.2 wt $\%$; FeO $13-14$ wt $\%$ ) in the remaining liquid is possible only when the crystallizing system follows the equilibrium crystallization path. The mineral compositions resulting from the models of the equilibrium and/or fractional crystallization are close to the actual one observed in the gabbros. The trace element distribution cannot be described with these simple models.

ii) Fractionation in periodically refilled (O'Hara, 1977; O'Hara \& Mathews, 1981) magma chambers offers an explanation to the occurrence of different mineral generations, particularly plagioclase, which is the first liquidus phase in this system. Neither equilibrium nor fractional crystallization modelling does display the remarkable $\mathrm{CaO}$-enrichment of the liquid path. A more dynamic path results from a continued series of cycles inside the magma chamber. As the initial magma is first subjected to fractional crystallization, the fraction of the remaining magma can erupt to the surface or continue to fractionate, and finally become contaminated by the wall rock and replenished by magma from a deeper source. Replenishment may take place in two ways: firstly, as batch replenishment where a chamber is filled with a discrete batch of magma through a short time interval or, secondly, as continuous replenishment over a long time interval. This process may be partly responsible for some restricted variation in incompatible element distribution in the Thverartindur samples.

Different mechanisms have been suggested for the evolution of Icelandic volcanics. In the recent Krafla volcanic system the AFM (assimilation-fractional crystallization) mechanism is believed to control the evolving magma system (Nicholson et al., 1991). This model takes into account lavas and other volcanic products which represent only the top "slice" of this crust-building environment. Process-oriented modelling should include additional "slices" of the plutonic formation, which may contain not less important imprints of "hidden" processes.

iii) Some of the Thverartindur samples that are referred to as hybrid, show a large chemical variation and more than one mineral generation requiring a different process, most likely magma mixing. In the Thverartindur plutonic formation, there occur two kinds of mixing. Firstly, the conventional case of acid-basic mixing, where less dense acid liquid enters into a basic magma chamber and produces an intermediate liquid observed in the intermediate dykes (Fig. 2). It is not obvious whether the mixing took place in a magma chamber or during the emplacement stage. Secondly, the mixing of two basic magmas of different compositions and different densities. An evolved quartz-tholeiitic magma may have been mixed with crystals from a more primitive parent. This can be successfully explained by equilibrium/fractional crystallization of olivine-tholeiitic magma where at the final stage (crystallinity around $70 \%$ ) the residual liquid was squeezed out capturing part of higher-temperature crystals, most likely plagioclase. This appears to be the case with hybrid samples with two distinctive generations of plagioclase without any smooth compositional change.

\section{CONCLUSIONS}

The plume influence in initial magma generation and magmatic evolution in crustal magma chambers inside the anomalously thick Icelandic crust $(8-20 \mathrm{~km})$ and later interaction with the altered old crust has created the specific chemistry of Icelandic rocks, such as high abundance of incompatible trace elements, high ${ }^{87} \mathrm{Sr} /{ }^{86} \mathrm{Sr}$, low ${ }^{143} \mathrm{Nd} /{ }^{144} \mathrm{Nd}$ and radiogenic $\mathrm{Pb}$ contents. 
Central volcanic systems along the rift zones modify the oceanic crust producing abundant evolved basaltic, intermediate, and rhyolitic rock types, which are not typical in the normal MORB environment. The Tertiary Thverartindur central volcanic complex in SE Iceland exhibits a large variation of rock types from ultramafic through olivine- and quartz-tholeiites, hybrid rocks to acid in the chemical composition. These rocks are developed as a result of multiple processes: i) fractional crystallization in a probably refilled crustal magma chamber; ii) mixing between basic and acid magmas, and mixing of the captured solidified crystals with more evolved basic magma. However, the $\mathrm{Fe}-\mathrm{Ti}$-enrichment accompanied by $\mathrm{Si}$ decrease in quartz-tholeiitic gabbros can be most easily obtained by a $50-70 \%$ crystallization of the olivine-tholeiitic composition following the equilibrium crystallization path.

\section{ACKNOWLEDGEMENTS}

This work was carried out during the Nordic research fellowship at Nordic Volcanological Institute, University of Iceland, Reykjavik. I would like to thank Karl Grönvold and Niels Oskarsson for guidance into modern basalt petrology and laboratory techniques. Review and constructive comments by K. Grönvold improved an earlier version of the manuscript.

\section{REFERENCES}

Annels, A. E. 1967. The geology of the Hornafjordur region. - PhD Thesis, University of London.

Biggar, G. M. 1983. Crystallization of plagioclase, augite and olivine in synthetic systems and in tholeiites. - Miner. Mag., 47, 161-176.

Bromann, M., Soesoo, A. 1994. Structure and petrology of a central volcanic complex in SE Iceland. (Abstract.) - Journal of Icelandic Geological Society, 29-30.

Blake, D. H. 1964. The volcanic geology of the Austurhorn area, south-eastern Iceland. $\mathrm{PhD}$ Thesis, University of London.

Blake, D. H. 1966. The net-veined complex of the Austurliorn intrusion, south-eastern Iceland. - J. Geol., 76, 891 -907.

Condomines, M. K., Grönvold, K., Hooker, P. J., Muehlenbachs, K., O’Nions, R. K., Oskarsson, N., Oxburgh, R. E. 1983. Helium, oxygen, strontium and neodymium isotopic relationship in Icelandic volcanics. - Earth. Planet. Sci. Lett., 66, $125-136$.

Furman, T., Frey, A. F., Meyer, P. S. 1992a. Petrogenesis of evolved basalts and rhyolites at Austurhorn, Southeastern Iceland: The role of fractional crystallization. J. Petrology, 33, 1405-1445.

Furman, T., Meyer, P. S., Frey, A. F. 1992b. Evolution of Icelandic central volcanoes: Evidence from the Austurhorn intrusion, southeastern Iceland. - Bull. Volcanol., $\mathbf{5 5}, 45-62$.

Gale, N. H., Moorbath, S., Simons, J., Walker, G. P. L. 1966. K-Ar ages of acid intrusive rocks from Iceland. - Earth. Planet. Sci. Lett., 1, 284-288.

Hemond, C., Arndt, N. T., Lichtenstein, U., Hofmann, W. 1993. The heterogeneous Iceland plume: $\mathrm{Nd}-\mathrm{Sr}-\mathrm{O}$ isotopes and trace element constraints. $-\mathrm{J}$. Geophys. Res., 98, 15833-15850.

Jakobsson, S. P., Jonsson, J., Shido, F. 1978. Petrology of the western Reykjanes Peninsula, Iceland. - J. Petrology, 19, 669-705.

Jakobsson, S. P. 1979. Outline of the petrology of Iceland. - Jökull, 29, 57-73. 
Kristjansson, L., Helgason, J. 1988. Some properties of basalt lava sequences and volcanic centres in a plate-boundary environment. - In: Early Tertiary volcanism and opening of the NE Atlantic, Geological Society Special Publication, 39, 147-155.

Mattson, S. R., Vogel, T. A., Wilbrand, J. T. 1986. Petrochemistry of the silicic-mafic complexes at Vesturhorn and Austurhorn, Iceland: Evidence for zoned/stratified magma. - J. Volcanol. Geotherm. Res., 28, 197-223.

McBirney, A. R., Naslund, H. L. 1990. The differentiation of the Skaergaard intrusion. Contrib. Mineral. Petrol., 104, 235-247.

Moorbath, S., Sigurdsson, H., Goodwin, R. 1968. K-Ar ages of the oldest exposed rocks in Iceland. - Earth. Planet. Sci. Lett., 4, 197-205.

Newman, T. C. 1967. The geology of some igneous intrusions in the Hornafjordur region, S. E. Iceland. - $\mathrm{PhD}$ Thesis, University of Manchester.

Nicholson, H., Condomines, M., Fitton, G. J., Fallick, A. E., Grönvold, K., Rogers, G. 1991. Geochemical and isotopic evidence for crustal assimilation beneath Krafla, Iceland. - J. Petrology, 32, 1005-1020.

O'Hara, M. 1977. Geochemical evolution during fractional crystallization of a periodically refilled magma chamber. - Nature, 266, 503--507.

O'Hara, M., Mathews, R. E. 1981. Geochemical evolution of an advancing, periodically tapped, continuously fractionated magma chamber. - J. Geol. Soc. London, 138, 237-277.

O'Nions, R. K., Hamilton, P. J., Evensen, N. M. 1977. Variation in ${ }^{143} \mathrm{Nd} /{ }^{144} \mathrm{Nd}$ and ${ }^{87} \mathrm{Sr} /{ }^{86} \mathrm{Sr}$ ratios in oceanic basalts. - Earth. Planet. Sci. Lett., 34, 13-22.

Oskarsson, N., Sigvaldason, G. E., Steinthorsson, S. 1982. A dynamic model of the rift zone petrogenesis and the regional petrology of Iceland. - J. Petrology, 23, $28-74$

Oskarsson, N., Steinthorsson, S., Sigvaldason, G. E. 1985. Iceland geochemical anomaly: Origin, volcanotectonics, chemical fractionation and isotope evolution of the crust. - J. Geophys. Res., 90, $10011-10025$.

Saemundsson, K. 1979. Outline of the geology of Iceland. - Jökull, 29, 7-28.

Steinthorsson, S., Oskarsson, N., Sigvaldason, G. 1985. Origin of alkali basalts in Iceland: A plate tectonic model. - J. Geophys. Res., 90, 10 027-10 042.

Walker, G. P. L. 1964. Geological investigations in eastern Iceland. - Bull. Volcanol., $27,3-15$.

White, R. S., McKenzie, D. 1989. Magmatism at rift zones: The generation of volcanic continental margins and flood basalts. - J. Geophys. Res., 94, 7685-7729.

Zindler, A., Hart, S. R., Frey, F. A., Jakobsson, S. P. 1979. Nd and Sr isotope ratios and rare earth element abundances in the Reykjanes Peninsula basalts: Evidence for mantle heterogeneity beneath Iceland. - Earth. Planet. Sci. Lett., 45, 249-262.

\title{
PLUTOONILISTE KIVIMITE MITMEKESISUS OOKEANI KOORES: THVERARTINDURI TSENTRAALNE VULKAANILINE KOMPLEKS KAGU-ISLANDIL
}

\author{
Alvar SOESOO
}

Islandi saar on osa Põhja-Atlandi ookeani koorest, kus ookeani keskahelik paljandub maismaal. Kagu-Island on läbi teinud ulatusliku glatsiaalse erosiooni, mille tulemusel on võimalik uurida geoloogilisi läbilõikeid, mis algselt olid maetud kahe kilomeetri sügavusele. Thverartinduri vulkaanilise kompleksi plutooniline osa koosneb tholeiitse seeria oliviin- ja kvartsnormatiivsetest gabrodest, hübriidsetest kivimitest ja suhteliselt laialdases mahus graniitsetest kivimitest. Ultraaluselised kivimid on esindatud sillide ja daikidena. Nimetatud kivimitüübid paljanduvad kahe 
paljufaasilise intrusioonina ja on geneetiliselt seotud ühise, maapinnalähedase magmakambriga. Kivimitüüpide mitmekesisus on tingitud erinevatest magmaprotsessidest, nagu: 1) fraktsiooniline ja tasakaaluline kristalliseerumine aeg-ajalt uuesti täidetud magmakambris; 2) väga mitmekesine aluselise magma ja happelise magma ning aluselise magma ja kristalliseerunud mineraalide segunemine, mis on arvatavasti aset leidnud nii magmakambris kui ka sillide formeerumise etapil. Kvartsnormatiivsed gabrod on raua- ja titaanirikkad, aga samas sisaldavad vähem ränioksiidi kui primitiivsemad oliviinnormatiivsed gabrod. On modelleeritud oliviinnormatiivse gabro kristalliseerumist Ni-NiO (NNO) ja kvarts-fajaliitmagnetiit (QFM) puhvrites, kusjuures parimad tulemused on saadud tasakaalulisel kristalliseerumisel NNO-puhvris. Pärast oliviin-tholeiitse magma 50-70\%-st kristallisatsiooni vastab jääkmagma pōhielementidelt kvartsnormatiivsete gabrode koostisele.

\title{
РАЗНООБРАЗИЕ ПЛУТОННЧЕСКИХ ПОРОД В ОКЕАНИЧЕСКОЙ КОРЕ: ТВЕРАТИНДУРСКИИ ЦЕНТРАЛЬНО-ВУЛКАНИЧЕСКИЙ КОМПЛЕКС В ЮГО-ВОСТОЧНОЙ ИСЛАНДИИ
}

\author{
Алвар COECOO
}

Исландия представляет собой часть океанической коры на севере Атлантики. Глубоко эродированный Твератиндурский комплекс сложен олевиновым и кварцевым габбро, гибридными и ультраосновными породами и гранитами. Названные породы картографированы на двух многофазных интрузивных массивах. Разнообразие плутонических пород океанической коры обусловлено разными магматическими процессами: фракционной н равновесной кристаллизацией, смешением разных магм, а также магм и кристаллов. Результаты моделирования кристаллизации олевин-нормативного габбро в NNO и QFM кислородных буферах показывают, что после 50-70\%-ной кристаллизации остающаяся часть магмы отвечает по составу главных элементов кварцевым габбро. 